\title{
THE AORIST AND THE PERFECT OF THE OLD INDIAN CAUSATIVES IN THE LIGHT OF NATURAL MORPHOSYNTAX
}

\begin{abstract}
The Old Indian causative conjugation features a reduplicated aorist and a periphrastic perfect. Within Natural Syntax, an attempt is made at predicting this state of affairs. Morphologically, the causative conjugation, the reduplicated aorist, and the periphrastic perfect are the most complicated structures within the verb system. The rules of alignment valid in Natural Syntax therefore predict the existing pairing of the two tenses within the causative conjugation.
\end{abstract}

***

In Slovenia, we study the behaviour of (near-)synonymous syntactic expressions, here called syntactic variants. Whenever two syntactic variants are included in the same naturalness scale, and consequently one variant can be asserted to be more natural than the other, something can be said about some grammatical properties of the two variants.

Naturalness values will be stated in naturalness scales. The basic format is $>$ nat (A, $B)$, i.e. with respect to cognitive complexity, $\mathrm{A}$ is more natural than $\mathrm{B}$.

In the present paper, the language examples are dealt with in »deductions. « Each deduction is valid only within the limits set by the language data stated at the beginning of any deduction.

Each deduction contains at least two naturalness scales. The naturalness values of paired scales will be aligned by the principle of markedness alignment as stated in Andersen 1968 (repeated in Andersen 2001), and adapted to naturalness in the following way: what is more natural tends to align with another instance of more natural; what is less natural tends to align with another instance of less natural.

A basic contribution of the $»$ Slovenian School « to Naturalness Theory is the follwing list of instructions (criteria) for determining naturalness in (morpho)syntax:

(A) The principle of least effort (Havers 1931:171). What conforms better to this principle is more natural. What is cognitively simple (for the speaker) is easy to produce, easy to retrieve from memory, etc.

(B) Phylogenetic age. What is older phylogenetically is more natural. What is cognitively simpler (for the speaker) is acquired earlier by the language.

(C) Prototypicality. What is nearer to the prototype is more natural.

(D) Degree of integration into the clause. What is better integrated into its clause is more natural. This partially exploits (C): the prototypical syntactic situation is for a syntactic element to be well integrated into its syntactic construction. 
(E) Frequency (in the spirit of Fenk-Oczlon 1991). What is more frequent in a language tokenwise is more natural. What is cognitively simpler (for the speaker) is used more. (However, the inverse situation does not obtain: what is natural is not necessarily frequent.)

(F) Small v. large class. The use of a unit pertaining to a small class is more natural than the use of a unit pertaining to a large class. During speech small classes are easier for the speaker to choose from than are large classes.

(G) Specialised v. non-specialised use. If there exists a specialised way of expressing a category, that specialised way is very natural as expression of the category in question. Suppose a language has reflexive personal pronouns. In that case, they are specialised to express reflexivity (whereas other personal pronouns are not specialised to express reflexivity, even if they may express it under certain circumstances), and their use to express reflexivity is very natural: $>$ nat (+reflexive, -reflexive) / personal pronoun as expression of reflexivity.

(H) Use v. non-use. The use of a category or process is more natural than its nonuse. This generalisation is based on the following consideration. All kinds of categories occur in the most natural lexical items, paradigms and constructions of the language, and ebb on the way out of that core. Take for example a language whose noun phrases distinguish singular, plural and dual. Although singular, plural and dual are not equally natural with respect to one another, each of them is highly natural in its own field. For instance, the dual is highly natural as an expression of duality: $>$ nat $(+,-) /$ dual in expressions of duality. This is correlated with the circumstance that the dual (in fact all three numbers) is present in personal pronouns, i.e. in the most natural noun phrases, while it may be present to different degrees in the remaining noun phrases of the language. The situation is similar with processes (such as raising); all processes are natural.

(I) Acceptable v. non-acceptable use. What is acceptable is more natural than what is not acceptable. The very reason for the acceptability of a syntactic unit is its greater naturalness with respect to any corresponding non-acceptable unit.

(J) What is more widespread in the languages of the world is more natural (the typological criterion). What is cognitively simpler (for the speaker) is realized in more languages.

The current version of criteria (A-J) has resulted from the cooperation of Janez Orešnik with Helena Dobrovoljc. Each of criteria (A-J) is assumed to indirectly inform us about what is easy or difficult for the cognitive activity in the human brain. Criterion (B) has recently been removed from this list.

Notice that the framework just outlined contains no generative component, and that it operates ex post facto.

(The above is from work by Janez Orešnik and is here published with permission. Janez Orešnik has also translated the present paper into English.) 
The Naturalness theory will here be applied to the Old Indian causative conjugation, which is different from all other conjugations in that it is paired (a) with a periphrastic perfect (involving the auxiliary 'do, make' or, more frequently, the auxiliary 'be'), and (b) with the reduplicated aorist. For the (philological) detail, see Whitney 1889:378 ff.

The question to be answered is, why the causative conjugation, of all conjugations, is combined with the two exceptional formations, the periphrastic perfect and the reduplicated aorist. More precisely, we shall enquire which presuppositions have to obtain so that this state of affairs becomes predictable. The answer will be couched in a deduction, as follows:

Old Indian. Of all the conjugations, only the causative one is combined with a periphrastic perfect.

The variants: the causative and the remaining conjugations.

1. The assumptions of Naturalness Theory:

1.1. >nat (other conjugations, causative conjugation)

I.e. the causative conjugation is less natural than other conjugations. - The internal structure of the causative conjugation is richer than the internal structure of the other conjugations. The speaker generates and pronounces the forms of the causative conjugation using more effort than handling the forms of other conjugations. Therefore the causative conjugation is the least natural conjugation by the criterion of least effort, item (a) in the list of criteria.

1.2. > nat (other perfects, periphrastic perfect)

I.e. the periphrastic perfect is less natural than the other perfects. - The same argumentation as sub 1.1 applies.

2. Rules of alignment:

2.1. $>$ nat tends to associate with another $>$ nat,

2.2. <nat tends to associate with another $<$ nat.

3. The consequences:

If the language distinguishes among a structurally most complicated conjugation (viz. the causative one) and structurally less complicated conjugations, such that one class of conjugations combines with the structurally most complicated perfect (viz. the periphrastic perfect), and the other class of conjugations combines with other perfects, then it is the structurally most complicated conjugation (viz. the causative one) which tends to combine with the structurally most complicated perfect (viz. the periphrastic perfect), and it is the structurally less complicated conjugations that tend to combine with other perfects. Q.E.D. (We do not expect the reverse state of affairs.)

4. Notes.

4.1. The reduplicated aorist is the structurally most complicated kind of aorist. The above deduction applies, mutatis mutandis.

4.2. The intensive and the desiderative are of similar structural complexity as the causative. They are not included above because the respective early philological evidence is so scarce as to be of no practical value here. 
In short, if it is accepted that the causative conjugation is the least natural conjugation, and if it is accepted that the periphrastic perfect is the least natural perfect (and if it is accepted that the reduplicated aorist is the least natural aorist), then it can be predicted that it is the causative conjugation that tends to combine with the periphrastic perfect (and with the reduplicated aorist).

$$
* * *
$$

\section{References}

ANDERSEN, Henning, 1968: IE. * $s$ after $i, u, r, k$ in Baltic and Slavic. Acta Linguistica Hafniensia 11, 171-190. ANDERSEN, Henning, 2001: Markedness and the theory of linguistic change. In: Henning Andersen (ed.):

Actualization: Linguistic change in progress. Amsterdam: Benjamins, 21-57.

Jamison, Stephanie W., 1983, Function and Form in the -áya-Formations in the Rig Veda and Atharva Veda.

Göttingen, Vandenhoeck \& Ruprecht.

Whitney, William D., 1889, Sanskrit grammar. The second edition. (The eleventh issue of 1667 was used.)

Cambridge, Mass., Harvard University Press.

\section{Povzetek \\ AORIST IN PERFEKT STAROINDIJSKIH KAVZATIVOV V LUČI NARAVNE OBLIKOSKLADNJE}

Staroindijska kavzativna spregatev vsebuje reduplicirani aorist in perifrastični perfekt. Članek skuša odgovoriti na vprašanje, pod katerimi predpostavkami se da ta konstelacija napovedati. Uporabljeni so prijemi naravne (obliko)skladnje.

Izhaja se iz okolnosti, da je kavzativna spregatev zgradbeno najbolj zapletena spregatev, da je reduplicirani aorist zgradbeno najbolj zapletena vrsta aorista in da je perifrastični perfekt zgradbeno najbolj zapletena vrsta perfekta. V okviru teorije naravnosti sledi, da je kavzativna spregatev najmanj naravna spregatev, reduplicirani aorist najmanj naravni aorist in perifrastični perfekt najmanj naravni perfekt. Po pravilih ujemanja med vrednostmi naravnosti se kavzativna spregatev poveže $\mathrm{z}$ redupliciranim aoristom in perifrastičnim perfektom. 